\section{Sequences of Probes Revealing Mapped Restriction Fragment-length Polymorphisms in Cucumber}

\author{
Michael J. Havey ${ }^{1}$ \\ Agricultural Research Service, U.S. Department of Agriculture, Department of \\ Horticulture, 1575 Linden Drive, University of Wisconsin, Madison, WI 53706
}

Additional index words. Cucumis sativus, cDNA, genomic, RFLP

\begin{abstract}
PstI-genomic and cDNA clones revealing mapped restriction fragment-length polymorphisms (RFLP) in cucumber (Cucumis sativus $\mathrm{L}$.) were sequenced in order to ensure that these clones remain available and to determine if any clones showing genetic linkage in cucumber are physically linked in Arabidopsis thaliana. Sequence comparisons using translated searches revealed that $80 \%$ of the cucumber cDNA clones showed significant ( $\leq \mathrm{e}-20)$ similarities to Arabidopsis expressed sequence tags (ESTs) or genomic sequences, as opposed to relatively few $(32 \%)$ of the cucumber genomic clones. Two clones revealing RFLPs linked at $2 \mathrm{cM}$ in cucumber showed significant $(\leq \mathrm{e}-20)$ similarities to sequences separated by 347,616 basepairs on chromosome 4 of Arabidopsis.
\end{abstract}

The development of a reasonably dense cucumber (Cucumis sativus L.) map in any given cross is challenging due to its extremely narrow genetic background (Dijkhuizen et al., 1996; Knerr et al., 1989). Nevertheless, many morphological (Fanourakis and Simon, 1987; Pierce and Wehner, 1990), isozyme (Meglic and Staub, 1996), and molecular markers (DaninPoleg et al., 2000; Kennard et al., 1994; Park et al., 2000; Serquen et al., 1997) have been mapped in cucumber. Segregation analyses of these molecular markers have been carried out using different crosses and the development of a consensus map of cucumber initiated (Bradeen etal., 2001). Because various molecularmarkers were identified and mapped by different laboratories using different crosses, it is imperative that all previously developed molecular markers are available to the cucumber research community. We completed over 700 hybridizations of random cDNA and genomic clones to reveal 89 restriction fragment-length polymorphisms (RFLPs) segregating in cucumber (Kennard et al., 1994; Park et al., 2000). Because these probes reveal polymorphic regions of the cucumber genome and may eventually be lost, deposition of their sequences into public databases will allow future researchers to isolate these genomic regions directly from cucumber DNA. Cucumber has a relatively small nuclear genome at 882 megabasepairs (mbp) per 1C (Ramachandran and Narayan 1985), about five times bigger than Arabidopsis thaliana at 172 mbp per 1C (Bennett and Smith 1991), and

\footnotetext{
Received for publication 16 Sept. 2003. Accepted for publication 30 Aug. 2004. Names are necessary to report factually on available data; however, the USDA neither guarantees nor warrants the standard of the product, and the use of the name by USDA implies no approval of the product to the exclusion of others that may also be suitable. The technical help of Vanessa Pope, Ruben Flores, and Tristen Gardner is gratefully acknowledged.

${ }^{1}$ USDA research geneticist and professor of horticulture. To whom correspondence should be addressed; e-mailmjhavey@wisc.edu.
}

any future sequencing of the cucumber nuclear genome will allow these RFLPs and adjacent quantitative trait loci(Kennard and Havey, 1995) to be placed on the physical map.

\section{Materials and Methods}

The origins of cDNA and PstI-genomic clones revealing RFLPs in cucumber were reported by Kennard et al. (1994). Growth of bacteria, purification of plasmids, cycle sequencing reactions, and sequence editing were carried out as described by Lilly and Havey (2001). In some cases sequencing the ends of specific clones did not overlap and two end sequences for a single clone were deposited in Genbank. Comparisons of cucumber sequences to Genbank EST and genomic databases were completed using the TBLASTXalgorithm(Altschul etal., 1997) with a score less than or equal to e-20 was considered as significant similarity. Relative positions of linked cucumber RFLPs and homologous Arabidopsis regions were compared using the highest significant hits to the Arabidopsis gene index at The Institute for Genomic Research (http://www.tigr.org/tdb/tgi/agi/).

\section{Results and Discussion}

The sequences of PstI-genomic (accession numbers 5175136 to 5175217 ) and cDNA (accession numbers CF542133 to CF542179) cDNA and genomic clones. Research (http://www.tigr.org/tdb/tgi/agi/). clones revealing mapped RFLPs in cucumber were deposited into Genbank. Comparisons using translated sequences (TBLASTX) revealed that $80 \%$ of the cucumber cDNA clones showed significant ( $\leq \mathrm{e}-20)$ similarities to Arabidopsis ESTs. Some of the cucumber cDNAs were similar to highly expressed genes, such as RuBISCO (CsC010), chlorophyll AB binding protein (CsC095), or polyubiquitin (CsC560). Relatively few (32\%) of the genomic clones showed significant $(\leq \mathrm{e}-20)$ similarities to Arabidopsis sequences.

Preliminary comparisons were made between genetic linkages in cucumber with physical positions in the Arabidopsis genome by requiring similarities of at least e-20 to an Arabidopsis EST or genomic region. Although there are relatively few RFLP markers in cucumber, a preliminary relationship was revealed between genetic linkage in cucumber and physical linkage in Arabidopsis. The sequences of two probes revealing RFLPs linked at $2 \mathrm{cM}$ in cucumber showed significant ( $\leq \mathrm{e}-20)$ similarities to sequences separated by 347,616 basepairs on chromosome 4 of Arabidopsis (Table 1). Other researchers have reported synteny across short recombinational distances between Arabidopsis and plants of families outside of the rosid II dicots (Chase et al., 1993), such as the Solanaceae (asterid I) (Fulton et al., 2002), and Fabaceae (rosid I) (Grant et al., 2000). For cucumber and other cucurbits (members of the rosid I group of dicots), there may exist regions of synteny with Arabidopsis over short recombinational distances that may aid in the identification of candidate genes.

\section{Literature Cited}

Altschul, S.F., T.L. Madden, A.A. Schäffer, J. Zhang, Z. Zhang, W. Miller, and D.J. Lipman. 1997. Gapped BLAST and PSI-BLAST: A new generation of protein database search programs. Nucl. Acids Res. 25:3389-3402.

Bennett, M.D. and J.B. Smith. 1991. Nuclear DNA amounts in angiosperms. Phil. Trans. Royal Soc. London (Series B-Biol. Sci.) 334:309-345.

Bradeen, J.M., J.E. Staub, C. Wye, R. Antonise, and J. Peleman. 2001. Towards an expanded and integrated linkage map of cucumber (Cucumis sativus L.). Genome 44:111-119.

Chase, M.W., D.E. Soltis, R.G. Olmstead, D. Morgan, D.H.Les, B.D. Mishler, M.R. Duvall, R.A. Price, H.G. Hills, and Y.L. Qiu. 1993. Phylogenetics of seed plants: an analysis of nucleotide sequences from the plastid gene rbcL. Ann. Miss. Bot. Gard. 80:528-580.

Danin-Poleg, Y., N. Reis, S. Baudracco-Arnas, M. Pitrat, J.E. Staub, M. Oliver, P. Arus, C.M. de

Table 1. Location of Arabidopsis sequences showing significant similarities to genetically linked cucumber

\begin{tabular}{|c|c|c|c|c|c|c|}
\hline \multicolumn{3}{|c|}{ Cucumber } & \multicolumn{4}{|c|}{ Arabidopsis $^{y}$} \\
\hline $\begin{array}{l}\text { Linkage } \\
\text { group }^{z}\end{array}$ & $\begin{array}{c}\text { Position } \\
\text { (cM) }\end{array}$ & Probe & Accession & $\begin{array}{c}\text { Similarity } \\
\text { score }\end{array}$ & Chromosome & Position \\
\hline $\mathrm{G}$ & 0 & CsC362 & NM_116345.1 & e-49 & 4 & 492,544 \\
\hline G & 2 & CsP441 & NM_116256.1 & e-20 & 4 & 144,928 \\
\hline G & 4 & $\mathrm{CsP} 280$ & NM_112261.2 & e-126 & 3 & $4,658,192$ \\
\hline G & 23 & CsC137 & NM_117862.1 & $\mathrm{e}-24$ & 4 & $8,745,286$ \\
\hline $\mathrm{G}$ & 26 & CsC588 & NM_124490.1 & e-75 & 5 & $20,386,302$ \\
\hline
\end{tabular}

${ }^{2}$ Cucumber linkage groups and positions in centiMorgans (cM) were reported by Kennard et al. (1994). y Arabidopsis accessions and positions corresponding to the most significant similarities to the cucumber clone. Positions shown in basepairs from 5' end in the Arabidopsis database at The Institute for Genomic 
Vicente, and N. Katzir. 2000. Simple sequence repeats in Cucumis mapping and map merging. Genome 43:963-974.

Dijkhuizen, A., W.C. Kennard, M.J. Havey, and J.E. Staub. 1996. RFLP variability and genetic relationships in cultivated cucumber. Euphytica 90:79-87.

Fanourakis, N.E. and P.W. Simon. 1987. Analysis of genetic linkage in cucumber. J. Hered. 78:138-242.

Fulton, T.M., R. van der Hoeven, N.T. Eannetta, and S.D. Tanksley. 2002. Identification, analysis, and utilization of conserved ortholog set markers for comparative genomics in higher plants. Plant Cell 14:1457-1467.

Grant, D., P. Cregan, and R.C. Shoemaker. 2000. Genome organization in dicots: genome duplication in Arabidopsis and synteny between soybean and Arabidopsis. Proc. Natl. Acad. Sci. (USA) 97:4168-4173.
Kennard, W.K., and M.J. Havey. 1995. Quantitative trait analysis of fruit quality in cucumber: QTL detection, confirmation, and comparison with mating-design variation. Theor. Appl. Genet. 91:53-61.

Kennard, W.K., K. Poetter,A. Dijkhuizen, V. Meglic, J.E. Staub, and M.J. Havey. 1994. Linkages among RFLP, RAPD, isozyme, disease resistance, and morphological markers in narrow and wide crosses of cucumber. Theor. Appl. Genet. 89:42-48.

Knerr, L.D., J.E. Staub, D.J. Holder, and B.P. May. 1989. Genetic diversity in Cucumis sativus L. assessed by variation at 18 allozyme loci. Theor. Appl. Genet. 78:119-128.

Lilly, J.W. and M.J. Havey. 2001. Short repetitive motifs contributed significantly to the huge mitochondrial genome of cucumber. Genetics 159:317-328.

Meglic, V. and J.E. Staub. 1996. Inheritance and link- age relationships of isozyme and morphological loci in cucumber (Cucumis sativus L.). Theor. Appl. Genet. 92:865-872.

Park, Y.H., S. Sensoy, C. Wye, R. Antonise, J. Peleman, and M.J. Havey. 2000. A genetic map of cucumber composed of RAPDs, RFLPs, AFLP markers and loci conditioning resistance to papaya ringspot and zucchini yellow mosaic viruses. Genome 43:1003-1010.

Pierce, L.K. and T.C. Wehner. 1990. Review of genes and linkage groups in cucumber. HortScience 25:605-615.

Ramachandran, C. and R.K.J. Narayan. 1985. ChromosomalDNAvariation in Cucumis. Theor Appl. Genet. 69:497-502.

Serquen, F.C., J. Bacher, and J.E. Staub. 1997. Mapping and QTL analysis of horticultural traits in a narrow cross in cucumber (Cucumis sativus L.) using random-amplified polymorphic DNA markers. Mol. Breed. 3:257-268. 